УДК 581.524.1

\title{
БІОРІЗНОМАНІТТЯ БАЛКОВОЇ СИСТЕМИ С. ТЕРЕШКІВКА СУМСЬКОГО РАЙОНУ ЯК ПЕРСПЕКТИВНОЇ ПРИРОДООХОРОННОЇ ТА РЕКРЕАЦІЙНОЇ ТЕРИТОРІЇ
}

\author{
Скляр Вікторія Григорівна \\ доктор біологічних наук, професор \\ Сумський національний аграрний університет, м. Суми, Україна \\ ORCID: 0000-0002-1301-7384 \\ skvig@ukr.net
}

Бондарєва Людмила Миколаївна

кандидат біологічних наук, доцент

Сумський національний аграрний університет, Суми, Україна

ORCID: 0000-0003-4126-7601

milabond77@gmail.com

Кирильчук Катерина Серіївна

кандидат біологічних наук, доцент

Сумський національний аграрний університет, Суми, Україна

ORCID: 0000-0001-9968-4833

ekaterinakir2017@gmail.com

Ємець Олександр Михайлович

кандидат біологічних наук, доцент

Сумський національний аграрний університет, м. Суми, Україна

ORCID: 0000-0003-1228-1439

Yemets_A@ukr.net

Баштовий Микола Григорович

кандидат біологічних наук, доцент

Сумський національний аграрний університет, м. Суми, Україна

ORCID: 0000-0002-3352-4375

bashtovoy.nik@gmail.com

Тебенко Юлія Михайлівна студентка ОС «Магістр»

Сумський національний аграрний університет, м. Суми, Україна tebenkojulia@gmail.com

Статя присвячена вивченню біорізноманіття балкової системи с. Терешківка Сумського району, з метою оцінки іï созологічної, наукової, освітньої, естетичної та рекреаційної цінності і надання даній території природоохоронного статусу. Польові дослідження балкової системи, яка розташовується на північному сході від с. Терешківка Сумського району і охополює площу близько 140 га, було проведено протягом 2019-2020рр. із використанням класичних геоботанічних та зоологічних методів. Вздовж досліджуваної території розташовуються сільськогосподарські угіддя, які захоплюють, у тому числі, $і$ схили балок, що загрожує иілісності ландшафотів $і є$ п причиною ерозії грунтів. Рослинні угруповання значною мірою відрізняються на різних ділянках балки, що пов'язано із відмінностями еколого-ценотичних умов у ї̈ межах. Південна (ближня до населеного пункту) частина балки являє собою систему суходільних лучних угідь, сфрормованих по дну та на схилах балки, які перебувають на різних стадіях пасовищної дигресії. Здебільшого це різнотравно-типчакові угруповання із переважанням на окремих ділянках Festuca ovina L., а на окремих Agrimonia eupatoria L.. На ділянці крутого схилу балки північно-східної експозиції у складі повзучемітлицевого угруповання виявлено популяцію регіонально рідкісного виду Jurinea cyanoides (L.) Reichenb., який також включений i до Додатку I Бернської конвенції. У відгалуженнях центральної частини балки відмічена наявність двох територіально відокремлених популяцій цінної лікарської рослини - Chamerion angustifolium (L.) Holub. У північній частині балки виявлено регіонально рідкісний вид Salix rosmarinifolia L. У списку фауни, серед безхребетних і птахів, є регіонально рідкісні види, які відповідно до статусу МСОП належать до категорії LC, а серед птахів значна кількість видів включена до переліку додатку II Бернської конвенції. Ссавці представлені переважно різноманітними гризунами. Серед плазунів трапляється вид Lacerta agilis, який занесений до додатку II Бернської конвениії і відповідно до MCOП має cтатус LC.

Таким чином, наявність у межах досліджуваної яружно-балкової системи видів, які репрезентують раритетну складову біорізноманіття, високе видове багатство, значні запаси лікарських рослин, а також із врахуванням наукової, пізнавальної, еколого-освітньої та рекреаційної цінності, вважаємо за доцільне роглядати балку, розташовану в околииях с. Терешківка, перспективною природоохоронною територією для створення ландшафртного заказника місцевого значення.

Ключові слова: природно-заповідний фонд, біорізноманіття, природні комплекси, созологічна цінність, фрлора, фрауна.

DOI https://doi.org/10.32845/agrobio.2021.2.8 
Вступ. Біорізноманіття включає у себе всі види живих організмів (на рівні популяцій, видів, екосистем, ландшафтів), які забезпечують функціонування біосфери. Його збереження виступає однією із глобальних екологічних проблем, рішенню яких присвячено низку наукових праць (Segelbacher, 2018; Sui et al. 2018; Kaur, 2018; Cardinale et al., 2011; Rahman, 2018; Wilsey 2018; Govorun et al., 2020; Dornelas, 2010; Movchan, 2000). Основною причиною зниження біорізноманіття $€$ деградація місць існування популяцій видів (Hellweg et. al., 2014; Dupuy \& Viñuales, 2018; Rabosky, 2009). Одним із шляхів їх збереження є створення і розширення об'єктів і територій природно-заповідного фонду (ПЗФ). Показником ефрективної роботи у цьому напрямі $€$ показник заповідності, що обчислюється як відношення площі заповідних територій до загальної площі певного регіону. На початок 2021 року за даними Державного кадастру ПЗФ відсоток заповідності території України складає 6,80 \% [Pryrodno-zapovidnyj fond, 2021], що втричі нижче за європейські країни, де він становить у середньому 21,0 \% [Smyrnova et al., 2021; Zakon Ukrai'ny «Pro Osnovni zasady (strategiju) derzhavnoi' ekologichnoi' polityky Ukrai'ny na period do 2030 roku», 2019]. Відповідно до Закону України «Про основні засади (стратегію) державної екологічної політики України на період до 2030 року» (28.02.2019 р., № 2697-VIII) необхідно збільшити площу ПЗФ до 15,0% [Zakon Ukrai'ny «Pro Osnovni zasady (strategiju) derzhavnoi' ekologichnoi' polityky Ukrai'ny na period do 2030 roku», 2019]. Саме тому тематика щодо вивчення територій, що потенційно можуть бути перспективними до заповідання, встановлення їх созологічної, наукової, освітньої, естетичної та рекреаційної цінності, є актуальною.

Відсоток заповідності Сумської області становить 7,49 \%, що вище, ніж у цілому, по Україні (Boychenko et al., 2019). Однак і він є суттєво нижчим від оптимального. Відповідно до розпорядження Кабінету Міністрів України № 443-р від 21.04.2021 р. «Про затвердження Національного плану дій з охорони навколишнього природного сере- довища на період до 2025 року» необхідно забезпечити збільшення площі заповідних територій на 3 \%, за рахунок створення нових або розширення площ вже існуючих територій та об'єктів ПЗФ [Nacional'ny] plan dij ohorony navkolyshn'ogo pryrodnogo seredovyshha do 2025 roku]. Роботи у цьому напрямку активно проводяться на території Сумської області [Sklyar \& Sklyar, 2003; Sklyar \& Sklyar, 2014; Sklyar et al., 2020; Govorun et al., 2020]. Це особливо важливо, враховуючи високий рівень розораності території України та подальший курс на інтесивне сільське господарство, що загрожує стійкому існуванню природних екосистем на територіях місцевих громад. Одним із таких об'єктів являється балкова система с. Терешківка Сумської області, окремі ділянки якої, у тому числі і схили, активно розорюються, а інша частина яружно-балкової системи знаходиться в умовах надмірного випасання та сінокосіння. Літературні дані щодо вивчення біорізноманіття даної території відсутні, що збільшує актуальність проведених регіональних досліджень.

Метою даного дослідження $€$ вивчення біорізноманіття балкової системи с.Терешківка Сумського району для оцінки її созологічної, наукової, освітньої та естетичної цінності і обгрунтування перспектив надання їй статусу природоохоронної території.

Матеріали і методи досліджень. Польові дослідження, результати яких покладено в основу даної публікації, проведені авторами протягом 2019-2020 рр. В їх основі лежать класичні геоботанічні та зоологічі методи [Polevaya geobotanika, 1959, Polevaya geobotanika, 1964; Jakubenko et al., 2018; Grishhenko, 1997]. Комплексна оцінка стану природних комплексів досліджуваної території проведена на основі географо-естетичної та психолого-естетичної оцінки її ландшафтів.

Досліджувана територія являє собою яружно-балкову систему, яка розташовується в околицях с. Терешківка Сумського району (рис. 1) і охоплює площу близько 140 га.

Публічна кадастрова карта України 5052'28.1»N 34³3'16.2»E. (https://map.land.gov.ua/).

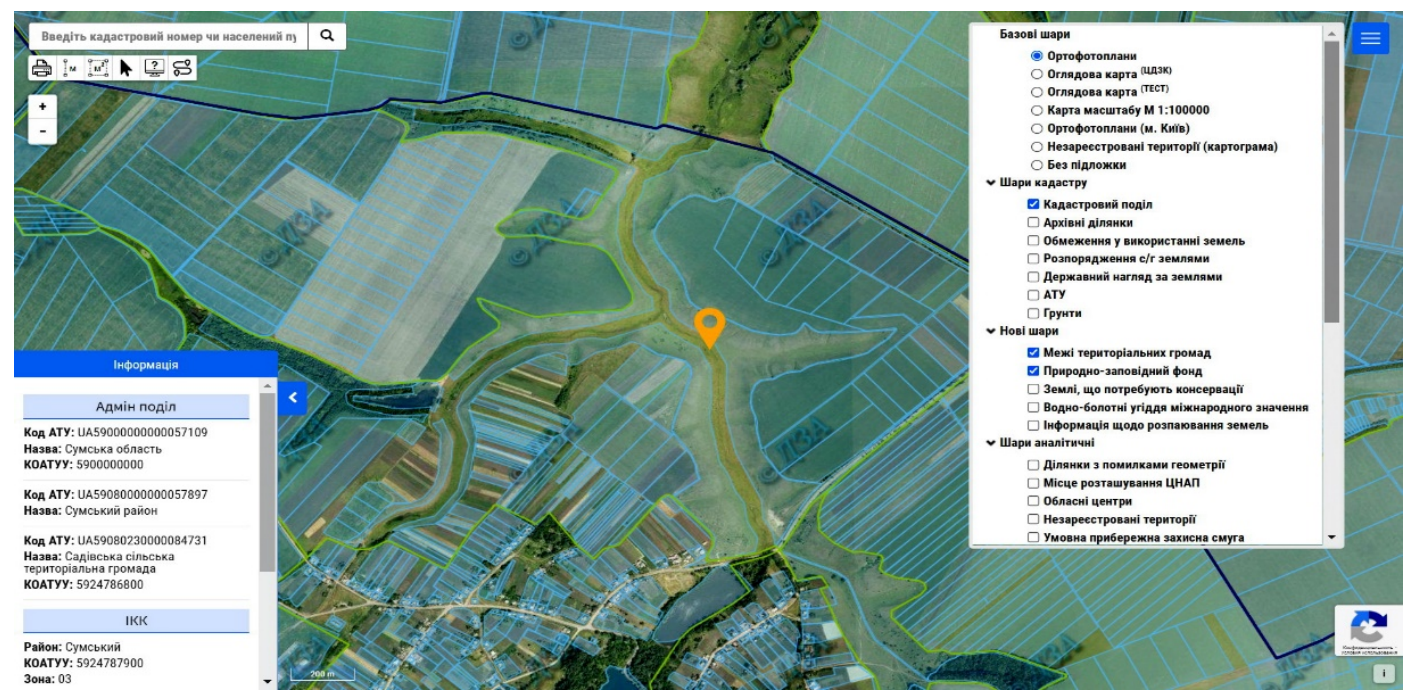

Рис. 1. Карто-схема яружно-балкової системи в околицях с. Терешківка 
Відповідно до фрізико-географічного районування України дана території відноситься до СтепанівськоХотінського району, Сумської схилово-височинної області Східно-Українського краю Лісостепової зони Східно-Європейської рівнини [Marynych et al., 1985]. А за геоботанічним районуванням - до Хотінського району Сумського округу Середньоросійської лісостепової підпровінції Східноєвропейської провінції Європейсько-Сибірської лісостепової області [Heobotanichne rajonuvannja Ukrai'ns'koi' RSR, 1977].

Територія, що підлягала вивченню, являє собою яружно-балкову систему, розташовану на північному сході від с. Терешківка. Вздовж неї розташовані сільськогосподарські угіддя (посіви кукурудзи та соняшника). Слід відмітити, що на окремих ділянках агрофітоценози захоплюють і схили балок (рис. 2), що є неприпустимим з точки зору збереження цілісності ландшафтів та запобігання ерозії грунтів.

Клімат Сумської області відрізняється більшою континентальністю, порівняно з центральними та західними областями України, що проявляється у збільшенні різниці літніх і зимових температур, а такожі меншою кількістю опадів (Boychenko et al., 2019). Середньодобова температура липня складає $19,0-21,0^{\circ} \mathrm{C}$, січня $--4,5^{\circ} \mathrm{C}-$ $-6,0^{\circ} \mathrm{C}$. Абсолютний максимум температур повітря становить $+40^{\circ} \mathrm{C}$, мінімум $--40^{\circ} \mathrm{C}$. Річна сума опадів 540-650 мм (Boychenko et al., 2019). Явища, пов'язані із кліматичними змінами на Землі, мають свої прояви і на території Сумської області (рис. 3) у вигляді аномально спекотного літа, зменшенні кількості опадів протягом вегетаційного періоду, що значною мірою також впливає на рівень грунтових вод.

Результати. Розміщення ділянок, охоплених дослідженнями, показано на рис. 4. Південна (ближня до населеного пункту) частина балки знаходиться на відстані близько 100 м від центральної дороги с. Терешківка та штучного ставка. Вона являє собою систему суходільних лучних угідь, сформованих по дну та на схилах балки, які перебувають у стадії пасовищної дигресії (передостаннього та останнього ступенів, до стадії збою

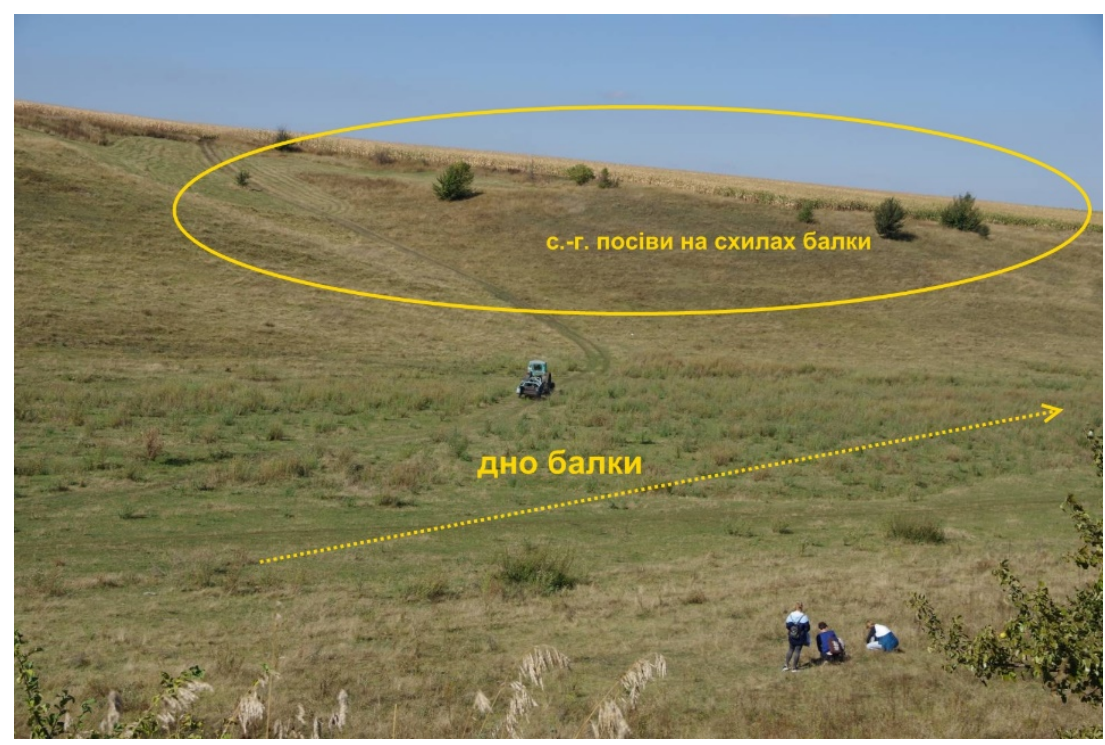

Рис. 2. Посіви с.-г. культур на схилах балки (фото М. Г. Баштового)

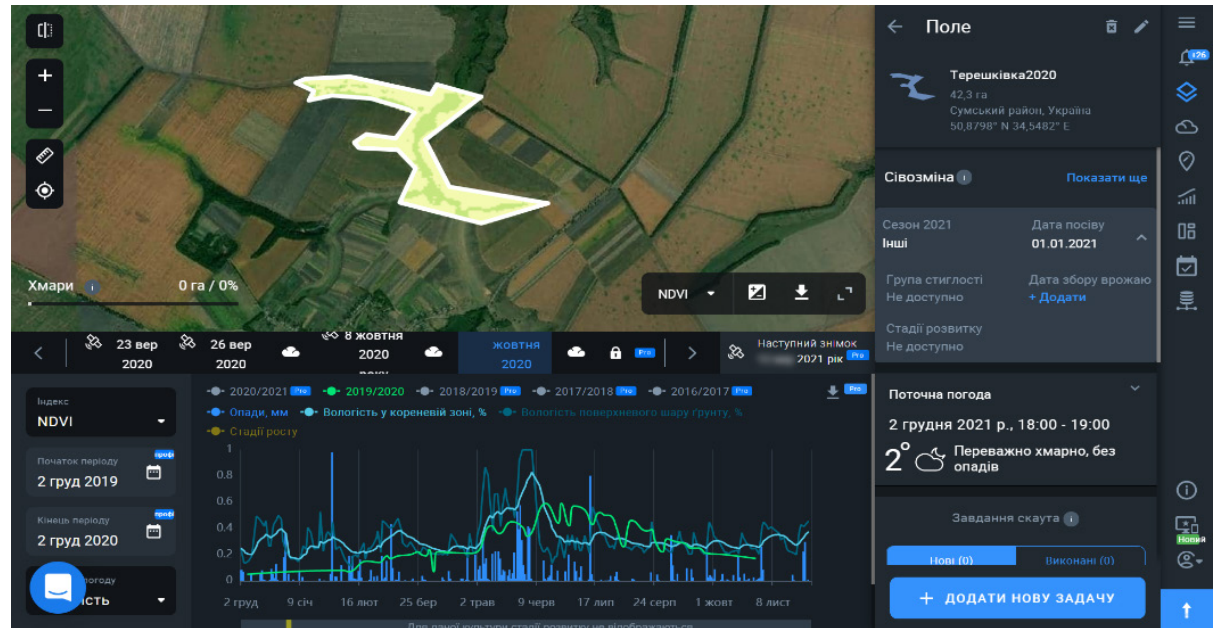

Рис. 3. Динаміка кліматичних умов та фотосинтетичної активності фітоценозів яружно-балочної ситеми протягом 2020-2021 років в околицях с. Терешківка 
із наявністю скотобійних плям та стежок). Ця частина балки використовується для випасання великої рогатої худоби та переміщення сільськогосподарської техніки.

Рослинність, сформована у цій частині балки, характеризується наявністю у складі фллори значної кількості отруйних, неїстівних, а також стійких до систематичних витоптувань та випасань видів. Здебільшого це різнотравно-типчакові угруповання із переважанням на окремих ділянках костриця овеча (Festuca ovina L.), а на окремих домінантним видом $€$ парило звичайне (Agrimonia eupatoria L.).

Ядро флористичного списку цього більш-менш одноманітного суходільного масиву виглядає наступним чином: костриця овеча (Festuca ovina L.), парило звичайне (Agrimonia eupatoria L.), трясучка середня (Briza media L., Sp. PI.), костриця лучна (Festuca pratensis Huds.), тонконіг лучний (Poa pratensis L.), лядвенець рогатий (Lotus corniculatus L.), миколайчики плоскі (Eringium planum L.) - до $10 \%$, кропива дводомна (Urtica dioica L.) - часто, нетреба звичайна (Xanthium strumarium L.), щавель кінський (Rumex confertus Willd.), полин гіркий (Artemisia absinthium L.) часто, синяк звичайний (Echium vulgare L.), гикавка сіра (Berteroa incana (L.) DC.), дивина лікарська (Verbascum phlomoides L.), фріалка триколірна (Viola tricolorL.), березка польова (Convolvulus arvensis L.), деревій майжезвичайний (Achillea submillefolium L.), материнка звичайна (Origanum vulgare L.), латук дикий (Lactuca serriola L.), морква дика (Daucus carota L.), дзвоники персиколисті (Campanula persicifolia L.), перстач повзучий (Potentilla reptans L.), перстач сріблястий (Potentilla argentea L.), будяк акантовидний (Cardus acanthoides L.), жовтозілля весняне (Senecio vernalis Waldst. \& Kit.), люцерна жовта (Medicago falcata L.), подорожник ланцетолистий (Plantago lanceolata L.), цикорій дикий (Cichorium intybus L.), любочки осінні (Leontodon autumnalis L.), куничник наземний (Calamagrostis epigeios (L.) Roth), сокирки польові (Consolida regalis Gray), підмаренник справжній (Galium verum L.), дзвоники розлогі
(Campanula patula L.), жовтозілля весняне (Senecio vernalis Waldst. \& Kit.), шавлія лучна (Salvia pratensis L.), кравник звичайний (Odontites vulgaris Moench), перстач неблискучий (Potentilla impolita Wahlenb.).

На ділянці крутого схилу балки північно-східної експозиції (місцезнаходження відмічено на рис. 3) у повзучемітлицевому угрупованні, на відстані 5-7 м від посіву кукурудзи, виявлено популяцію юринеї волошкової (ю. несправжньоволошковидної, ю. харківської): Jurinea cyanoides (L.) Reichenb. (J. pseudocyanoides Klokov; J. charcoviensis Klokov). Цей вид включено до «Переліку видів рослин, тварин і грибів, що підлягають особливій охороні на території Сумської області», а також до «Бернської конвенції» (Резолюція № 6). На південно-східному схилі балки наявні глиняні відслонення.

Дистальна (північна) частина балки закінчується лучно-болотними ділянками із переважанням гідрофільної фрлори серед трав'янистої та деревно-чагарникової рослинності. У відгалуженнях центральної частини балки сформувались угруповання із переважанням видів, що пристосовані до середнього рівня зволоження, а також видів мезо-гігроффітної екології (фрагментами). Окремо слід відмітити, що серед деревних видів і чагарників зустрічаються синантропні види, що вказує на наявність на цих територіях штучних приватних насаджень у минулому. Найбільш поширені: бузина чорна (Sambucus nigra L.), вільха чорна (Alnus glutinosa (L.) Gaertn.), верба п'ятитичинкова (Salix pentandra L.), верба козяча (Salix caprea L.), айва довгаста (Cydonia oblonga Mill.), шипшина травнева (Rosa majalis Herrm.), груша дика (Pyrus communis L.), клен американський (Acer negundo L.). I3 трав'янистих видів: грястиця збірна (Dactylis glomerate L.), пирій повзучий (Elytrigia repens (L.) Desv. ex Nevski), осока рання (Carex praecox Schreb.), парило звичайне (Agrimonia eupatoria L.), полин гіркий (Artemisia absinthium L.), татарник звичайний (Onopordum acanthium L.), лопух справжній (Arctium lappa L.), собача кропива пятилопа'тева (Leonorus quinquelobatus Gilib.), кропива дводомна (Urtica dioica L.), деревій майже зви-

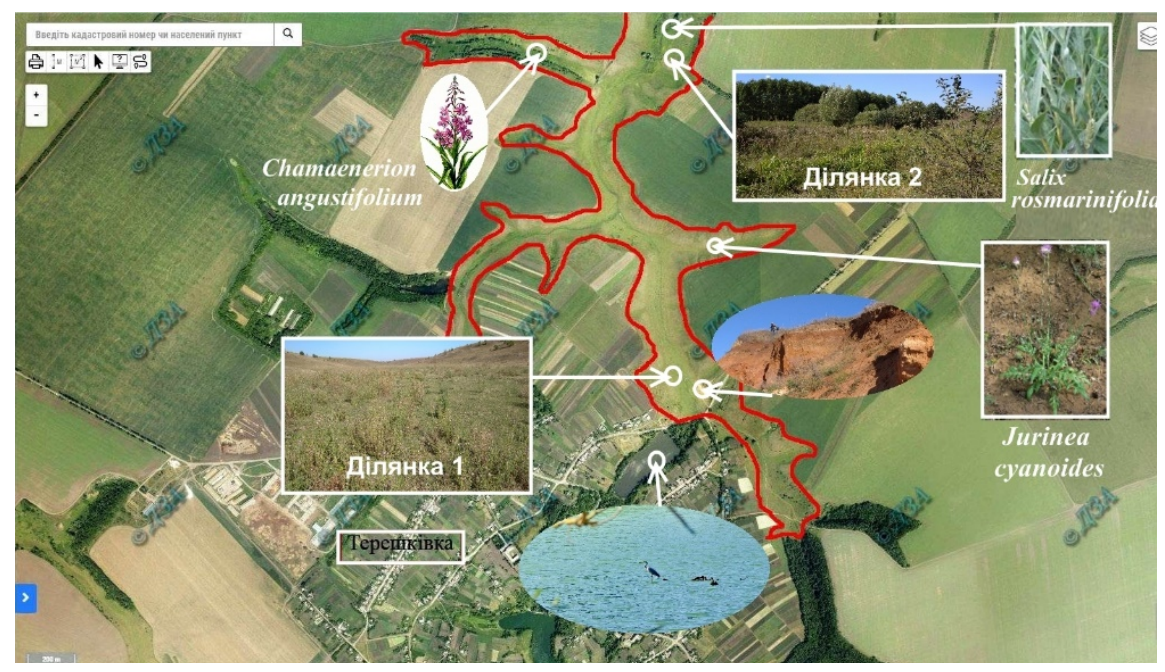

Рис. 4. Контури ділянок в околицях с. Терешківка, детально охарактеризованих у тексті звіту (впорядковано Л. М. Бондарєвою)

Вісник Сумського національного аграрного університету 
чайний (Achillea submillefolium Willd.), любочки осінні (Leontodon autumnalis L.), дивина лікарська (Verbascum phlomoides L.), суниці лісові (Fragaria vesca L.). y цій частині балки відмічена наявність двох відокремлених територіально популяцій цінної лікарської рослини - зніту вузьколистого, (Іван-чаю) (Chamerion angustifolium (L.) Holub, син. Epilobium angustifolium). Після детального популяційного дослідження віталітетного стану і позитивних висновків щодо самовідтворення цього виду, а також за умов дотримання необхідних правил, ділянки можуть бути рекомендовані для надання дозволів заготівлі лікарської рослинної сировини, або ж для збору насіння з метою культивації цього виду (місцезнаходження популяцій наведено на рис. 3).

Дослідна Ділянка № 2 (рис. 3) розташована в північній частині балки і представлена видами мезо-, мезо-гігро, гігро- та гідрофітами. Тут зростають очерет південний (Phragmites australis (Cav.) Trin. ex Steud.), комиш лісовий (Scirpus sylvaticus L.), осока побережна (Carex riparia Curtis), рогіз широколистий (Typha latifolia L.), хвощ річковий (Equisetum fluviatile L.), мітлиця повзуча (Agrostis stolonifera L.), череда трироздільна (Bidens tripartita L.), вербозілля звичайне (Lysimachia vulgaris L.), гадючник в'язолистий (Filipendula ulmaria (L.) Maxim.), вовконіг європейський (Lycopus europaeus L.), череда трироздільна (Bidens tripartita L.), гравілат річковий (Geum rivale L.), жовтозілля болотне (Senecio paludosus L.), жовтий осот болотний, (Sonchus palustris L.), очанка стиснута (Euphrasia stricta J.P. Wolff ex J.F.Lehm.). Серед деревно-чагарникової рослинності переважає вільха чорна (Alnus glutinosa (L.) Gaertn.), також відмічено наявність трьох видів верб: верби п'ятитичинкової (Salix pentandra L.), верби козячої (Salix caprea L.) і виду із природоохоронним статусом як регіонально рідкісний - верби розмаринолистої (Salix rosmarinifolia L.) місцезнаходження наведено на рис. 3.

На дещо підвищених територіях (по периметру) зростають плакун верболистий (Lythrum salicaria L.), підмаренник чіпкий (Galium aparine), кропива дводомна (Urtica dioica L.), перстач гусячий (Potentilla anserina L.), сідач конопляний (Eupatorium cannabinum L.), жовтець їдкий (Ranunculus acris L.), вербозілля лучне (Lysimachia nummularia L.), лопух велики (Arctium lappa L.), цикорій дикий (Cichorium intybus L.), тимофіївка лучна (Phleum pratense L.), стенактис однорічний (Stenactis annua (L.) Cass.).

Таким чином, обстежена територія включає як антропогенно трансформовані ділянки із збідненим фрлористичним складом і деградованими грунтами, так i, хоч і невеликі, але осередки збереженої природної біоти (у т.ч. і видів з природоохоронним статусом), що можуть слугувати своєрідним «резервом» для відновлення природної фрлори на цих ділянках у випадку встановлення контролю за понаднормованим антропогенним тиском.

Остепнені лучні ценози в основному заселені різноманітними безхребетними, переважно комахами та, меншою мірою, павукоподібними. Комах репрезентують типові для таких ценозів представники прямокрилих, рівнокрилих та метеликів, меншою мірою жуків, пере- тинчастокрилих та двокрилих. Типовими у цих умовах є трав'янка зелена (Omocestus viridulus Linnaeus,1758), трав'янка струнка (Stenobothrus stigmaticus Rambur, 1839), кобилка чорносмуга (Oedaleus decorus Germar, 1825), цвіркун польвий (Gryllus campestris Linnaeus, 1758), летюха звичайна (Aiolopus thalassinus Fabricius, 1781), мурашка садова чорна (Lasius niger Linnaeus,1758), джміль садовий (Bombus hortorum Linnaeus, 1758), дзюрчала осоподібна (Temnostoma vespiforme Linnaeus, 1758), джміль польовий (Bombus pascuorum Scopoli, 1763), бархатниця волоока (Maniola jurtina Linnaeus, 1758), сонцевик павичеве око (Inachis io Linnaeus,1758), білан ріп'яний (Pieris rapae Linnaeus,1758), рябокрилка мінлива (Araschnia levana Linnaeus,1758), голубінка ікар (Polyommatus icarus Rottemburg, 1775), бабка жовта (Sympetrum flaveolum Linnaeus,1758), коник зелений (Tettigonia viridissima Linnaeus,1758) тощо. 3 числа безхребетних трапляються види з охоронними статусами, зокрема: бабка жовта, джміль садовий та польовий, які за версією МСОП мають охоронний статус рівня LC.

Хребетні тварини використовують лучні ценози переважно як кормові локації. На досліджуваній території трапляються: лелека білий (Ciconia ciconia Linnaeus, 1758), ворон (Corvus corax Linnaeus,1758), ластівка сільська (Hirundo rustica Linnaeus,1758), плиска жовта (Motacilla flava Linnaeus,1758), лисиця звичайна (Vulpes vulpes Linnaeus, 1758).

За оцінками МСОП вище названі тварини мають охоронний статус рівня LC. Лелека білий занесений до списку регіонально рідкісних птахів Сумської області. Слід також відмітити, що усі перераховані птахи є у переліку додатку II Бернської конвенції.

3 числа чагарникових птахів на досліджуваній території поширені кропив'янка сіра (Sylvia communis Latham, 1787), кропив'янка садова (Sylvia borin Boddaert, 1783), чекан луговий (Saxicola rubetra Linnaeus, 1758), які мають охоронний статус MCOП рівня LC та занесені до Додатку II Бернської конвенції. Ссавці представлені переважно різноманітними гризунами, серед яких типовими є миша польова (Apodemus agrarius Palls, 1771) та нориця звичайна (Microtus arvalis Pallas, 1778). 3 числа плазунів зрідка трапляється ящірка прудка (Lacerta agilis Linnaeus,1758), яка має охоронний статус МСОП рівня LC та занесена до Додатку II Бернської конвенції.

3 метою комплексної оцінки стану природних комплексів цієї території, була здійснена географо-естетична та психолого-естетична оцінка її ландшафтів (табл. 1, 2).

Відповідно до сумарної географо-еститичної оцінки ландшафту біля с. Терешківка досліджувана яружно-балкова система має 10,5 балів. За психологоестетичною оцінкою ландшафт балки с. Терешківка набирає 18,5 балів, що відповідає діапазону 16,124,0 балів, та дає всі підстави рекомендувати ії для створення на ній обєкту ПЗФ місцевого значення.

Обговорення. Подібні дослідження відіграють важливе значення на шляху створення нових і розширення вже існуючих об'єктів ПЗФ на рівні окремих регіонів, що безумовно сприяє поліпшенню охорони біорізноманіття на різних рівнях організації (видовому, популяційному, 
Таблиця 1

Географо-естетична оцінка ландшафту балки с. Терешківка

\begin{tabular}{|c|c|c|c|c|}
\hline \multirow{3}{*}{ № } & \multirow{3}{*}{ Критерій } & \multicolumn{3}{|c|}{ Бал } \\
\hline & & \multicolumn{2}{|c|}{ точка } & \multirow{2}{*}{ середній } \\
\hline & & 1 & 2 & \\
\hline 1 & Гармонія природних та антропогенних об'єктів & 2 & 2 & 2 \\
\hline 2 & $\begin{array}{l}\text { Наявність на ділянці мальовничих урочищ, затишних куточків, } \\
\text { де приємно відпочивати, насолоджуватись красою природи }\end{array}$ & 2 & 2 & 2 \\
\hline 3 & $\begin{array}{c}\text { Наявність на ділянці визначних пам'яток, таких як химерні скелі, } \\
\text { водоспади, вікові дерева, скупчення чарівних рослин, квітів, } \\
\text { пам'ятки історії та культури }\end{array}$ & 2 & 2 & 2 \\
\hline 4 & $\begin{array}{c}\text { Наявність на ділянці оглядових майданчиків, } \\
\text { з яких відкриваються гарні краєвиди }\end{array}$ & 2 & 1 & 1,5 \\
\hline 5 & Виразність фрорм рельєфу & 1 & 1 & 1 \\
\hline 6 & Виразність водних об'єктів & 0 & 0 & 0 \\
\hline 7 & Різноманітність і чергування рослинних угруповань & 1 & 1 & 1 \\
\hline 8 & Різноманітність тваринного світу ділянки & 1 & 1 & 1 \\
\hline & Сумарний бал за критеріями & & & 10,5 \\
\hline
\end{tabular}

Таблиця 2

Психолого-естетична оцінка ландшафту балки с. Терешківка

\begin{tabular}{|c|c|c|c|c|}
\hline \multirow{2}{*}{ № опорної точки і характер пейзажу, що відкривається } & \multicolumn{4}{|c|}{ Оцінка за критеріями балів } \\
\hline & 1. (C) & 2. (3) & 3. $(\mathrm{H})$ & 4. (Д) \\
\hline 1. Лучна ділянка на схилі & 2 & 2 & 2 & 2 \\
\hline 2. Ділянка у підніжжя схилу & 2 & 2 & 2 & 2 \\
\hline Середній бал по кожному з критеріїв & 2 & 2 & 2 & 2 \\
\hline Сума середніх балів за всіма критеріями & \multicolumn{4}{|c|}{8,0} \\
\hline Сума за даними таблиць 1 та 2 & \multicolumn{4}{|c|}{18,5} \\
\hline Висновок & \multicolumn{4}{|c|}{$\begin{array}{c}\text { Загальний бал відповідає діапазону 16,1-24,0: ділянка } \\
\text { може бути рекомендована для створення на ній } \\
\text { об'єкту ПЗФ місцевого значення. }\end{array}$} \\
\hline
\end{tabular}

фітоценотичному, екосистемному), а також на різних територіальних рівнях (насамперед регіональному та державному). Ефективність впровадження природохоронних заходів значно підвищиться за умови оголошення у межах балки території природно-заповідного фонду. Цій території пропонується надати статус ландшафтного заказника місцевого значення, а повну назву об'єкту прийняти такою: ландшафтний заказник місцевого значення «Степне».

У межах території, яка була охоплена вивченням та висувається для надання природохоронного статусу, у подальшому важливою складовою системи заходів із забезпечення охорони популяцій видів, які репрезентують раритетну складову біорізноманіття, мають стати моніторингові дослідження. У зв'язку з тим, що балка безпосередньо межує із територіями, на яких здійснюється активна сільськогосподарська діяльність, збереження популяцій рідкісних видів (тварин, рослин), залежить і від дотримання вимог екологічного законодавства при господарюванні на прилеглих землях, та загалом переведення різних форм господарської діяльності людини на екологічно безпечні технології. У загальному розумінні це характеризують як впровадження екологічної конверсії виробництв та дотримання екологічного імперативу (Sheljag-Sosonko, 2001). Зазначені підходи розглядаються як невід'ємна складова екологізації соціальних та виробничих процесів, і посідають провідне місце в низці пропонованих на XXI ст. сценаріїв виходу із світової екологічної кризи (Zlobin et al., 2013).

На сучасному етапі здійснюється формування поліфункціональної парадигми охорони природи, яка буде передбачати охорону на всіх рівнях організації біосистем (Sheljag-Sosonko et al., 1992). Успішність її впровадження значною мірою залежить і від екологобіологічної освіченості всіх прошарків суспільства та розуміння громадянами об'єктивних законів, які обумовлюють стійкість біосфери та природного середовища. Тобто невід'ємною складовою заходів, спрямованих на охорону біорізноманіття, має стати і системна еколого-просвітницька робота із населенням, яке проживає на територіях (або біля них), що є осередками поширення рідкісних видів. Вона може реалізовуватися і через формування екологічних стежок (маршрутів) (Caryk \& Caryk, 2019) у межах балки та проведення на них різноманітних рекреаційних заходів, екскурсій, при суворому дотриманні правил поведінки у природі та нормативних вимог щодо можливих обсягів і інтенсивності рекреаційних навантажень. Останні мають визначатися як на основі відповідних законодавчих (нормативних) документів (Metodychni rekomendacii', 2003, Babjuk, 2012), так і за результатами моніторингових досліджень у межах даної балкової системи.

Висновки. Результати проведеного аналізу свідчать про значну естетичну цінність балкової системи 
та доцільність її залучення до складу природно-заповідного фонду. Зважаючи на наявність у ії межах видів, що репрезентують раритетну складову біорізноманіття, що охороняється як на регіональному, так і на міжнародному рівнях, високе видове багатство та значні запаси лікарських рослин, популяції яких можуть розгляда- тися як генетичні резервати цих цінних видів, а також із врахуванням наукової, пізнавальної, еколого-освітньої та рекреаційної цінності, вважаємо за доцільне роглядати балку, розташовану в околицях с. Терешківка, перспективною природоохоронною територією у ранзі заказника місцевого значення.

\section{Бібліографічні посилання:}

1. Babjuk, L. M. (2012). Ekologo-geografichni pidhody shhodo racional'nogo vykorystannja rekreacijnyh resursiv zapovidnyh terytorij (na materialah ekostezhok Seredn'ogo Podnistrov'ja [Ecological and geographical approaches to the rational use of recreational resources of protected areas (based on eco-trails of the Meddle Transnistria]. Avtoref. dysertacii' na zdobuttja naukovogo stupenja kandydata geografichnyh nauk za spec 11.00.11.- konstruktyvna geografija ta racional'ne vykorystannja pryrodnyh resursiv. L'viv, 20 (in Ukrainian).

2. Boychenko, R. V., Vertel, V. V., Karlyukova, O. Yu., Panchenko, S. M., Kryvozub, I., Dudchenko, G., Kulyzhko, I., Kubrakov, S., Stryzhak, A., \& Yakovenko, O. (2019). Pryrodno-zapovidnyi fond Sumskoi oblasti: Atlas-dovidnyk (2yi-e, vypr. ta dopov. vyd.) [Nature Reserve Fund of Sumy Region: Atlas-Handbook (2nd ed., Corrected and supplemented ed.)]. TOV «Ukrainska Kartohrafichna Hrupa», Kyiv, 96 (in Ukrainian).

3. Cardinale, B. J., Matulich, K. L., Hooper, D. D., Byrnes , J. E., Duffy, E., Gamfeldt , L., Balvanera, P., O'Connor, M. I. \& Gonzalez, A. (2011). The functional role of producer diversity in ecosystems. American Journal of Botany, 98(3), 572-592. doi: $10.3732 / a j b .1000364$

4. Caryk, L., \& Caryk, P. (2019). Do problemy reguljuvannja rekreacijnyh navantazhen' ekologo-osvitnih stezhok ustanov pryrodno-zapovidnogo fondu [To the problem of regulation of recreational loads of ecological-educational paths of institutions of nature reserve fund]. Racional'ne pryrodokorystuvannja i ohorona pryrody Naukovi zapysky, 2, 163-172 (in Ukrainian). doi: 10.25128/2519-4577.19.3.20

5. Grishhenko, V. N. (1997) Provedenie oprosov naselenija dlja sbora faunisticheskoj informacii [Conducting the survey among the public to fauna information collecting]. Obliki ptahiv: pidhodi, metodiki, rezul'tati, L'viv, Kiiiv, 72-75 (in Russian).

6. Dornelas, M. (2010). Disturbance and change in biodiversity. Phil. Trans. R. Soc. B365, 3719-3727. doi: 10.1098/ rstb.2010.0295

7. Dupuy P., Viñuales, J. (2018). International Environmental Law (2nd ed.). Cambridge: Cambridge University Press. doi: $10.1017 / 9781108399821$

8. Govorun, O. V., Sira, O. Je., Vertel', V. V., \& Darmostuk, V. V. (2020). «Vakalivs'ki shyly» - potencijnyj landshaftnyj zakaznyk miscevogo znachennja na Sumshhyni [«Vakalivsky slopes» - projected local nature reserve in Sumy region]. Visnyk SumNAU. Serija Agronomija i biologija, 2020, 1(39), 19-25. doi: 10.32845/agrobio.2020.1.3

9. Heobotanichne rajonuvannja Ukrai'ns'koi' RSR / AN URSR, (1977) [Geobotanic zoning of Ukrainian SSR]. In-t botaniky im. M. G. Holodnogo. Nauk. dumka, Kyiv (in Ukrainian).

10. Hellweg, S., Mila, I., \& Canals, L. (2014). Emerging approaches, challenges and opportunities in life cycle assessment. Science, 344 (6188), 1109-1113. doi: 10.1126/science.1248361

11. Jakubenko, B. Je., Popovych, S. Ju., Utymenko, P. M., Dubyna, D. V., \& Churylov, A. M. Heobotanika: metodychni aspekty doslidzhen'. (2018). [Geobotany: methodological aspects of research]. Vyd-vo Lira-K, Kyiv (in Ukrainian).

12. Kaur, A. (2018) Conservation of Plant Biodiversity Current Strategies and Future Needs. International Journal of Scientific Research in Biological Sciences, 5(4), 109-113. doi: 10.26438/ijsrbs/v5i4.109113

13. Marynych, A. M., Pashhenko, V. M., \& Shyshhenko, P. G. (1985). Pryroda Ukraynskoj SSR. Landshafty y fyzykogeografycheskoe rajonyrovanye [Nature of Ukrainian SSR. Landscapes and physico-geographical zoning]. Nauk. dumka, Kyi'v.

14. Metodychni rekomendacii' shhodo vyznachennja maksymal'nogo rekreacijnogo navantazhennja pryrodnyh kompleksiv i ob'jektiv u mezhah pryrodno-zapovidnogo fondu Ukrai'ny za zonal'no-regional'nym rozpodilom [Methodical recommendations for determining the maximum recreational load of natural complexes and objects within the nature reserve fund of Ukraine by zonal-regional distribution] (2003). Kyi'v, 43 (in Ukrainian).

15. Movchan, Ja. I. (2000). Zberezhennja biorozmai'ttja Ukrai'ny (kontekst ekopolityky) [Conservation of the biodiversity of Ukraine (ecopolitics context)], 18, II, Naukovi zapysky NaUKMA, Kyiv (in Ukrainian).

16. Nacional'nyj plan dij ohorony navkolyshn'ogo pryrodnogo seredovyshha do 2025 roku [National plan for the protection of the natural environment until 2025]. [Electronic resource]. Access mode: https://www.kmu.gov.ua/npas/pro-zatverdzhennyanacionalnogo-planu-dij-z-ohoroni-navkolishnogo-prirodnogo-seredovishcha-na-period-do-2025-roku-i210421-443

17. Polevaya geobotanika. (1959). [Field geobotany]. Izdatel'stvo Akademii Nauk SSSR, Moskva, 1 (in Russian).

18. Polevaya geobotanika. (1964). [Field geobotany]. Nauka, Moskva-Leningrad, 3 (in Russian)

19. Rahman, M.A. (2018) Plant diversity in Hazarikhil Wildlife Sanctuary of Chittagong and its conservation management. Journal of Biodiversity Conservation and Bioresource Management, 3(2), 43-56. doi: 10.3329/jbcbm.v3i2.36027

20. Segelbacher, G. (2018). Genetic, genomic, synthetic - new approaches for biodiversity conservation. Proceedings of the 5th European Congress of Conservation Biology. ECCB2018: 5th European Congress of Conservation Biology. 12th-15th of June 2018, Jyväskylä, Finland. doi: 10.17011/conference/eccb2018/107508

21. Sheljag-Sosonko, Ju. R., Ustymenko, P. M., \& Popovych, S. Ju. (1992). Strategija polifunkcional'noi' ohorony pryrodnyh terytorij [Strategy of multifunctional protection of natural territories]. Tezy dopov. IH z'i'zdu UBT. Naukova dumka, Kyi'v, 174-175 (in Ukrainian).

22. Sheljag-Sosonko, Ju. R. (2001). Bioresursy: stan ta analiz dysbalansiv [Bioresources: status and analysis of imbalances]. Pryrodno-resursnyj aspekt rozvytku Ukraïny. KM Academia, Kyiv, 40-74 (in Ukrainian). 
23. Sklyar, V. H., \& Sklyar, Yu. L. (2003). Systemnyy pidkhid do optymizatsiyi okhorony pryrodnykh kompleksiv [Integrated approach to optimization of protection of natural complexes].Ukrai'ns'kyj botanichnyj zhurnal, 60(4), 388-396 (in Ukrainian).

24. Sklyar, V. H., \& Sklyar, Yu. L. (2014). Stvorennya novykh terytoriy pryrodno-zapovidnoho fondu yak vazhlyvyy skladnyk rozbudovy strukturnykh elementiv ekomerezhi Polis'koyi chastyny Sums'koyi oblasti [Creation of new territories of the nature reserve fund as an important component of the development of structural elements of anecological network of the Polissia part of Sumy region]. Naukovyy visnyk Skhidnoyevropeys'koho Natsional'noho universytetu im. Lesi Ukrayinky. Seriya «Biolohichni nauky», 13(290), 61-66 (in Ukrainian).

25. Sklyar, V. G., Sklyar, Ju. L., Bashtovyj, M. G., Lytovka, V. V., Jemec', O. M., Sherstjuk, M. Ju., \& Jaroshenko, N. P., Goven'ko Ja. S. (2020). Bioriznomanittja proponovanogo zakaznyka «Pshinchyne» [Biodiversity of the proposed reserve "Pshinchyne"]. Visnyk SumNAU. Serija Agronomija i biologija, 3(41), 41-48. doi: 10.32845/agrobio.2020.3.5

26. Smyrnova, S. M., Mas', Ju. A, Koval', A. O. (2021). Jevropejs'kyj dosvid zemlekorystuvannja pryrodno-zapovidnogo fondu [European esperience of land use of nature reserve fund]. Ekonomika i derzhava, 1, 77-82. doi: 10.32702/2306-680 6.2021.1.77

27. Sui, X., Mao, L., Liu, Y., \& He, F. (2018). Mapping relative extinction risk for biodiversity conservation. Biological Conservation, 226, 168-176. doi: 0.1016/j.biocon.2018.07.012

28. Pryrodno-zapovidnyj fond [Nature reserve fund] (2021). Sajt Ministerstva zahystu dovkillja ta pryrodnyh resursiv Ukrai'ny. [Electronic resource]. Access mode: https://wownature.in.ua/oberihaymo/pryrodno-zapovidnyy-fond/

29. Rabosky, D. L., (2009). Ecological limits and diversification rate: alternative paradigms to explain the variation in species richness among clades and regions. Ecology Letters, 12(8), 735-743. doi: 10.1111/j.1461-0248.2009.01333.x

30. Wilsey, B. J. (2018). Biodiversity of Grasslands. Oxford Scholarship Online. doi: 10.1093/oso/9780198744511.003.0002

31. Zakon Ukrai'ny «Pro Osnovni zasady (strategiju) derzhavnoi' ekologichnoi' polityky Ukrai'ny na period do 2030 roku» [Law of Ukraine "on the Basic Principles (Strategy) of the State Environment Policy of Ukraine for the period up to 2030"]. (2019). URL: https://zakon.rada.gov.ua/laws/show/2697-19\#Text

32. Zlobin, Ju. A., Skljar, V.G., \& Klimenko, A.O. (2013). Populjacii redkih vidov rastenij: teoreticheskie osnovy i metodika izuchenija [Population of rare plant species: theoretical foundations and research methods]. Universitets'ka kniga, Sumy, 439 (in Russian).

Skliar V. G., Doctor (Biological Sciences), Professor, Sumy National Agrarian University, Sumy, Ukraine

Bondarieva L. M., PhD (Biological Sciences), Associate Professor, Sumy National Agrarian University, Sumy, Ukraine

Kyrylchuk K. S., PhD (Biological Sciences), Associate Professor, Sumy National Agrarian University, Sumy, Ukraine

Yemets O. M., PhD (Biological Sciences), Assistant Professor, Sumy National Agrarian University, Sumy, Ukraine

Bashtovyi M. G., PhD (Biological Sciences), Associate Professor, Sumy National Agrarian University, Sumy, Ukraine

Tebenko Yu. M., Student, Sumy National Agrarian University, Sumy, Ukraine

Biodiversity of the balk system of Tereshkivka village (Sumy district) as a perspective environmental and recreational territory

The article is devoted to the study of biodiversity of the balk system of Tereshkivka village (Sumy district), in order to assess its sozological, scientific, educational, aesthetic and recreational value and give this area environmental status. The field studies of the balk system, which is located northeast of the village Tereshkivka of Sumy region and covers an area of about 140 ha, was carried out during 2019-2020 using classical geobotanical and zoological methods. Along the study area there are agricultural lands, which include the slopes of the balk, that threaten the integrity of landscapes and is the cause of soil erosion. Phytocenoces differ significantly in different parts of the balk due to differences in ecological and coenotic conditions. The southern (closed to the village) part of the balk is a system of dry meadow lands formed on the bottom and on the slopes of the balk, which are at different stages of pasture digression. These are mostly herbaceousfescue groups with dominance in some areas of Festuca ovina L. and in some areas of Agrimonia eupatoria L. A population of the regionally rare species Jurinea cyanoides (L.) Reichenb., which is also included in Annex I of the Berne Convention, was found in the area of the steep slope of the northeastern exposition balk as a part of Agrostis stolonifera plant coenosis. In the branches of the central part of the balk the presence of two territorially separated populations of the valuable medicinal plant - Chamerion angustifolium (L.) Holub. was noted. A regionally rare species of Salix rosmarinifolia L. has been found in the northern part of the balk. In the fauna list, among the invertebrates and birds, there are regional rare species, which according to the IUCN status belong to the LC categories, and among birds a significant number of species are listed in Annex II of the Berne Convention. Mammals are represented mainly by a variety of rodents. Among the reptiles there is Lacerta agilis species - the species from the Annex II of the Berne Covention and according to IUCN has the status of LC.

So, the presence within the studied balk system of the species representing a rare component of biodiversity, high species richness, significant reserves of medicinal plants, as well as taking into account scientific, cognitive, environmental, educational and recreational value, we consider that balk system located near the village Tereshkivka is a perspective protected area for the creation of landscape reserve of local importance.

Key words: nature reserve fund, biodiversity, nature complexes, sozological value, flora, fauna. 